\title{
Article \\ Sorrentina Peninsula: Geographical Distribution of the Indoor Radon Concentrations in Dwellings-Gini Index Application
}

\author{
Filomena Loffredo ${ }^{1,2, *(\mathbb{D})}$, Irene Opoku-Ntim ${ }^{3} \mathbb{D}$ and Maria Quarto ${ }^{1,2} \mathbb{D}$ \\ 1 Advanced Biomedical Science Department, University of Naples, 80131 Naples, Italy; maria.quarto@unina.it \\ 2 Advanced Metrological and Technological Services (CeSMA), University of Naples, 80138 Naples, Italy \\ 3 National Nuclear Research Institute, Ghana Atomic Energy Commission, Accra GW-0373-819, Ghana; \\ ina82ma@gmail.com \\ * Correspondence: filomena.loffredo@unina.it
}

Citation: Loffredo, F.; Opoku-Ntim, I.; Quarto, M. Sorrentina Peninsula: Geographical Distribution of the Indoor Radon Concentrations in Dwellings-Gini Index Application. Appl. Sci. 2021, 11, 7975. https:// doi.org/10.3390/app11177975

Academic Editors: Vittoria D'Avino and Mariagabriella Pugliese

Received: 7 July 2021

Accepted: 25 August 2021

Published: 28 August 2021

Publisher's Note: MDPI stays neutral with regard to jurisdictional claims in published maps and institutional affiliations.

Copyright: (C) 2021 by the authors Licensee MDPI, Basel, Switzerland. This article is an open access article distributed under the terms and conditions of the Creative Commons Attribution (CC BY) license (https:// creativecommons.org/licenses/by/ $4.0 /)$.

\begin{abstract}
The radon isotope $\left({ }^{222} \mathrm{Rn}\right.$, half-life 3.8 days $)$ is a radioactive byproduct of the ${ }^{238} \mathrm{U}$ decay chain. Because radon is the second biggest cause of lung cancer after smoking, dense maps of indoor radon concentration are required to implement effective locally based risk reduction strategies. In this regard, we present an innovative method for the construction of interpolated maps (kriging) based on the Gini index computation to characterize the distribution of Rn concentration. The Gini coefficient variogram has been shown to be an effective predictor of radon concentration inhomogeneity. It allows for a better constraint of the critical distance below which the radon geological source can be considered uniform, at least for the investigated length scales of variability; it also better distinguishes fluctuations due to environmental predisposing factors from those due to random spatially uncorrelated noise. This method has been shown to be effective in finding larger-scale geographical connections that can subsequently be connected to geological characteristics. It was tested using real dataset derived from indoor radon measurements conducted in the Sorrentina Peninsula in Campania, Italy. The measurement was carried out in different residences using passive detectors (CR-39) for two consecutive semesters, beginning in September-November 2019 and ending in September-November 2020, to estimate the yearly mean radon concentration. The measurements and analysis were conducted in accordance with the quality control plan. Radon concentrations ranged from 25 to $722 \mathrm{~Bq} / \mathrm{m}^{3}$ before being normalized to ground level, and from 23 to $933 \mathrm{~Bq} / \mathrm{m}^{3}$ after being normalized, with a geometric mean of $120 \mathrm{~Bq} / \mathrm{m}^{3}$ and a geometric standard deviation of 1.35 before data normalization, and $139 \mathrm{~Bq} / \mathrm{m}^{3}$ and a geometric standard deviation of 1.36 after data normalization. Approximately $13 \%$ of the tests conducted exceeded the $300 \mathrm{~Bq} / \mathrm{m}^{3}$ reference level set by Italian Legislative Decree 101/2020. The data show that the municipalities under investigation had no influence on indoor radon levels. The geology of the monitored location is interesting, and because soil is the primary source of Rn, risk assessment and mitigation for radon exposure cannot be undertaken without first analyzing the local geology. This research examines the spatial link among radon readings using the mapping based on the Gini method (kriging).
\end{abstract}

Keywords: radon; Sorrentina peninsula; Gini method; kriging

\section{Introduction}

Ionizing radiation exposure, both for the general public and for specialists, is a cuttingedge research topic. Ionizing radiation can originate from both natural and man-made sources [1,2]. In particular, the radiation of natural origin (understood as background radiation), includes three main components: (i) cosmic rays [3]; (ii) cosmogenic radioisotopes; (iii) and primordial radioisotopes [4].

The majority of natural radioactivity is due to a terrestrial component created by primordial radionuclides that produce three decay series: ${ }^{238} \mathrm{U},{ }^{235} \mathrm{U}$, and ${ }^{232} \mathrm{Th}$. Each of these decay series produces radon isotopes. The ${ }^{222} \mathrm{Rn}$ isotope and its decay products are 
the most abundant source of natural ionizing radiation, accounting for the vast majority of the effective dose to human life. Epidemiological studies have discovered a relationship between radon concentration exposure and the risk of lung cancer [5-8]. Dense radon concentration maps are required to execute successful locally based risk reduction efforts, with geostatistical interpolation approaches possibly inferring the expected concentration when fewer data are available.

The Council Directive 2013/59/Euratom [9], which Italy enacted in July 2020 (Legislative Decree 101/2020), was the first control for radon exposure in homes in the European Union. As a result, Member States must promote public awareness about indoor radon danger. According to the literature, soil is the major source of radon. In this context, it is believed that the radon concentrations following the geological map are spatially linked and give rise to stationary distributions, at least over restricted areas. Indoor concentration measurements, in contrast, are impacted by a number of factors and hence display significant fluctuation, resulting in spatially non-stationary distributions of values.

As a result, applying interpolation techniques based on variogram calculation, such as kriging, can be difficult because these techniques must be implemented using advanced fits (such as nested structures) or after data preprocessing [10].

To address these constraints, several writers devised a new technique based on the calculation of the Gini index, a tool typically employed in the socio-economic sector for income distribution studies but with applicability in a wide range of disciplines [11,12].

Indoor radon measurements in Sorrentina peninsula homes were conducted voluntarily by families that attended a scientific presentation [13]. Individuals spend most of their time at home, i.e., at least $30 \%$ of the day. In this investigation, roughly 70 houses (measurement locations) were employed to evaluate the spatial distribution of the yearly average concentration of $\mathrm{Rn}$. This sample size is adequate for creating indoor $\mathrm{Rn}$ maps of the predicted average concentration in the Sorrentina peninsula area using geostatistical methods.

To ensure the radon measurements were independent of the floor on which they were obtained, the first step was to normalize the data with respect to the ground floor. The Gini index was used to create the interpolated maps for this case study [12-14]. This index is bounded above because it can only take on a value of one, implying that it may make detecting quasi-stationarity distributions more difficult. In such instances, computing the classical semi-variogram may be required to confirm the quasi-stationarity. The Gini index distinguishes fluctuations caused by environmental factors from those caused by random spatially uncorrelated noise, and also allows a better constraint of the critical distance below which the radon geological source can be considered to be uniform, at least for the length scales of variability studied.

In the sections that follow, we first provide a brief review of the literature on the methodologies used to map radon distribution in the State of the Art section (Section 2). The important information relating to the indoor radon monitoring that was performed, and the tools utilized to perform both statistical and geographic analysis, are presented in the Materials and Methods section (Section 3). Finally, we present and discuss the collected results (Sections 4 and 5), and we finish by proposing future advances (Section 6).

\section{State of the Art}

A significant portion of the scientific community has been active in evaluating the risk of radon exposure and identifying locations with high concentrations, both locally and globally, by conducting studies in various countries. Several initiatives to construct radon potential maps have been completed, and more are underway [15-20].

The most fundamental geostatistical techniques are based on two phases known as variogram fit and kriging [21]. The variogram provides a quantitative estimate of the spatial autocorrelation of a sparse dataset. Based on this autocorrelation, kriging can interpolate the provided dataset, producing predicted values on a finer grid with a predetermined resolution. 
The desired geographic resolution and the specific application necessitate the selection of the mapping technology.

Kriging is the best estimator for spatial analysis because it is non-polarized. There are several varieties of kriging, including Simple Kriging (SK), Ordinary Kriging (OK), Universal Kriging, and CoKriging (multivariate geostatistics). Furthermore, alternative methodologies for this research, such as fractal and multi-fractal analysis, Bayesian spatial quantile regression, and standard multivariate statistical algorithms, have been presented in the literature [22-28]. Although this information is useful for effective radon management, the uncertainty associated with simulations is often not fully considered for interpretation purposes [29].

Finally, other studies have applied logistic regression models to estimate the probability that the indoor Rn concentration exceeds a certain fixed value (for example the maximum reference level for the law in force) [30]. The major requirements are data uniformity and robustness, especially if the dataset employed is not designed for a certain technique.

Correct application of these approaches, and the correct interpretation of the results, provides knowledge about the system's underlying variability structure. This is appropriate for any type of spatial study aimed at modelling the trend in variability and developing appropriate spatial models. Several studies have established that geological data and indoor radon levels are sufficient factors for obtaining indoor radon maps [29,31].

\section{Materials and Methods}

\subsection{Sorrentina Peninsula}

The Sorrentina peninsula covers an area of roughly $200 \mathrm{~km}^{2}$ and is one of Campania's most famous tourist sites (see Figure 1). It is the distal part of the Lattari Mountains' carbonate ridge located on the Tyrrhenian Sea, separating the Gulf of Naples from the Gulf of Salerno. It is located in the territory of the provinces of Naples, which has 9 municipalities, and Salerno, which has 12 municipalities.

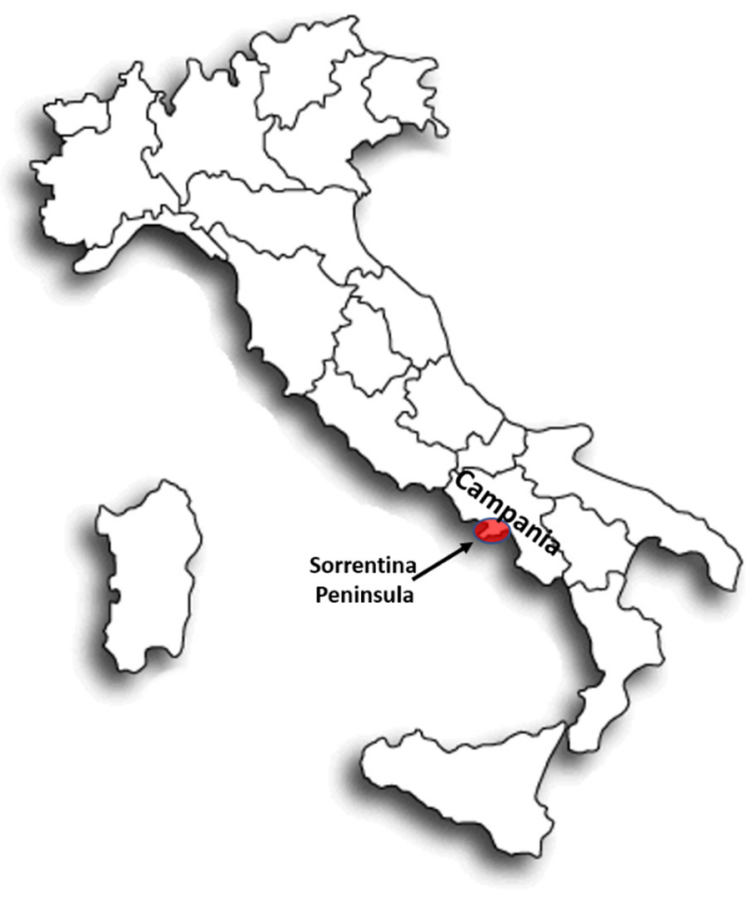

Figure 1. Sorrentina Peninsula, Campania, Southern Italy, study area.

The trunkline extends NE-SW and is arranged transversely to the Apennine chain. In the section from Sella di Cava dei Tirreni to Punta Scutolo, the backbone comprises a huge sequence of limestone and dolomitic rocks (Meta). The peninsula's structural 
configuration began to diversify around the end of the Upper Pliocene, and the subsequent transcurrent and extensional Plio-Quaternary tectonics [32]. The Sorrentina Peninsula is distinguished by an alternating pattern of high and low coastal sectors, many of which have been heavily impacted by tectonic and volcanic activities [33-35]. The substrate is covered by Quaternary deposits, such as carbonate debris and incoherent volcanoclasticites of various sizes attributed to Campania's volcanic activity during the upper Pleistocene period, in addition to reduced gravel and sandy deposits of ancient beaches, both recent and current.

\subsection{Indoor Radon Monitoring}

Radon levels were measured in 100 residences in six of the nine municipalities (Figure 2). A questionnaire was issued to residents to obtain information regarding the building's features. Radon concentration measurements were mainly taken in the bedroom, where most people spend at least $30 \%$ of their time, using solid state nuclear detectors (CR39). The measurements began in September-November 2019 and completed in September-November 2020. To determine the average annual radon concentration, the CR39 detectors were exposed for two consecutive semesters. The measurements were carried out by the Radioactivity Laboratory (lab.RAD, University of Naples Federico II, Naples, Italy), which is certified to the ISO 9001:2015 standard and accredited to the European Standard EN ISO/IEC 17025 for the "integrated measurement method for determining average activity concentration of radon 222 in the environment air using passive sampling and delayed analysis" (UNI ISO 11665:2020, part 4). After the exposure, the CR-39 detectors were chemically etched, using a solution of $6.25 \mathrm{M} \mathrm{NaOH}$ at $98{ }^{\circ} \mathrm{C}$ for $60 \mathrm{~min}$. The track density was determined by acquiring the image of the detector using a Politrack (Mi.am) automatic counter of track density. After reading the tracks, the concentration was calculated using the relationship:

$$
C_{R n}=\frac{N}{E \times T}
$$

where $N\left(\right.$ tracks $\left./ \mathrm{cm}^{2}\right)$ is the track density corrected by background track density, $E$ (tracks $\mathrm{cm}^{-2} / \mathrm{Bq} \mathrm{m}{ }^{-3} \mathrm{~h}$ ) is the calibration factor, and $T(\mathrm{~h}$ ) is the exposure time.

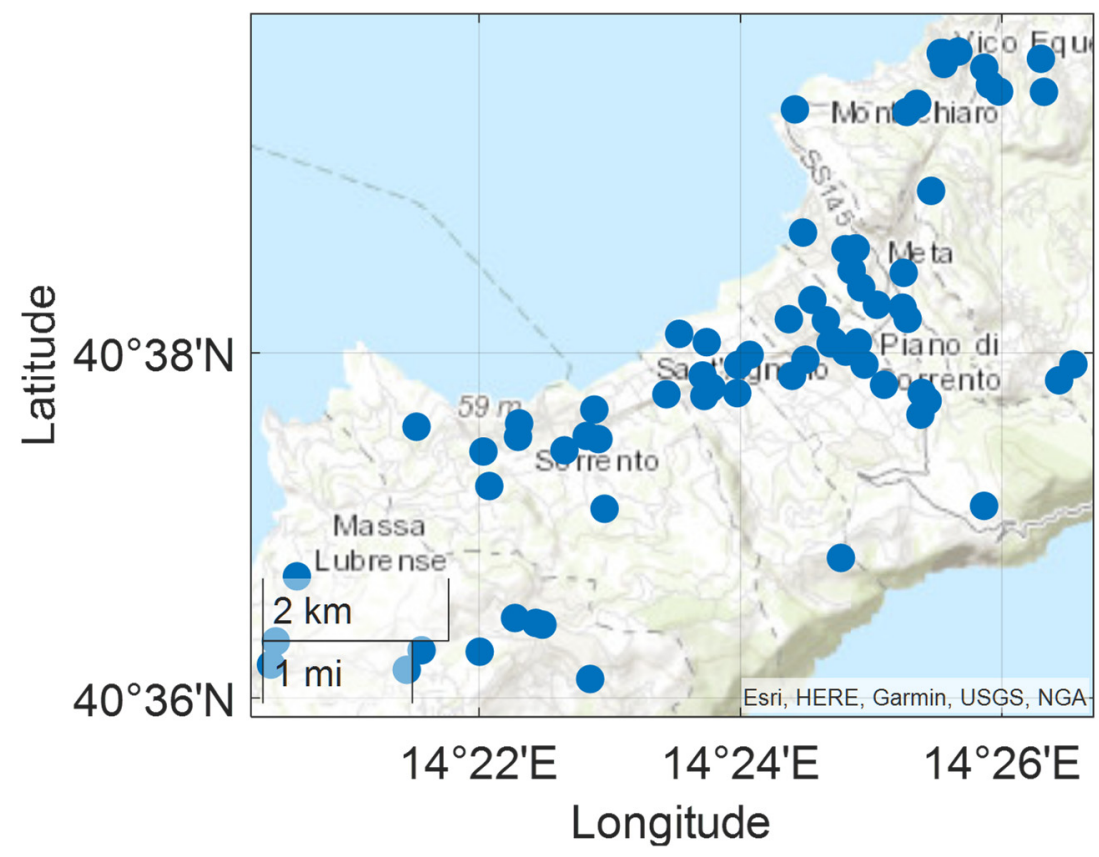

Figure 2. Indoor radon measurement points on the Sorrentina peninsula. 
Once the exposure times $\Delta t_{1}$ and $\Delta t_{2}$ were known, the average annual concentration was determined as follows:

$$
C_{R n}^{T}=\frac{\left(\Delta t_{1} \times C_{R n}^{1}\right)+\left(\Delta t_{2} \times C_{R n}^{2}\right)}{\left(\Delta t_{1}+\Delta t_{2}\right)}
$$

where $C_{R n}{ }^{1}$ and $C_{R n}{ }^{2}$ are the integrated measured radon concentrations determined in the first and second semester, respectively.

A comparison exercise coordinated by the German Federal Office for Radiation Protection (BfS) was used to ensure the overall quality of the procedure.

Figure 2 shows the distribution of the indoor radon measurement points on the Sorrentina Peninsula, and, in particular, in the area that concerns the six municipalities (Massa Lubrense, Meta, Sant'Agnello, Sorrento, Piano di Sorrento, and Vico Equense).

\subsection{Data Correction}

Indoor radon concentrations are influenced by several factors related to the monitored homes, such as construction materials and floor. Concrete (in approximately 70 homes) was determined to be the most commonly used construction material, which, according to the literature, is the material that contributes the least to indoor radon concentrations. The analysis was limited to these residences in order to exclude the influence of construction materials on the radon levels.

The dependence on the floor is concerned was eliminated by performing normalization. The conversion factor $K_{i \rightarrow 0}$ at the $i$-th floor with respect to the ground floor is defined as shown below:

$$
K_{i \rightarrow 0}=\frac{G M^{(0)}}{G M^{(i)}}
$$

where $G M^{(0)}$ is the geometric mean of measurements taken at the ground floor whereas $G M^{(i)}$ is the same mean related to the floor.

$$
C=K_{i \rightarrow 0} C_{y}^{(i)}
$$

where $C_{y}^{(i)}$ is the original and $C$ is the normalized radon concentration [36].

\subsection{Statistical Analysis}

To determine the annual average radon concentration for each measurement site, the time-weighted average radon concentration from two consecutive semesters was calculated using the exposure time, indicated in hours, as a weight. The Kolmogorov-Smirnov and Shapiro-Wilk tests were used to determine the normality of the log-transformed data. The analysis of variance was used to compare multiple groups (ANOVA). The Statistical Package for the Social Sciences was used for all statistical analyses (IBM SPSS Statistic 26).

\subsection{Spatial Analysis}

Most basic geostatistical approaches are based on two phases known as variogram fit and kriging [21]. The variogram provides a quantitative measure of a sparse dataset's spatial autocorrelation. Based on this autocorrelation, kriging can interpolate the given dataset, computing predicted values on a finer grid with a predefined resolution.

In this context, we offer a new method for the creation of interpolated maps (kriging) based on the Gini index $[12,14]$ to characterize the distribution of Rn concentration. According to Loffredo et al., 2021, it is best practice to undertake data processing to ensure the hypothesis of stationarity (ergodicity).

The Gini-based semivariogram is shown below, and is based on the Gini index, which is defined as:

$$
\gamma_{G}\left(h_{k}\right)=\left[\frac{1}{n-1} \sum_{i=1}^{n}\left|z\left(x_{i}\right)-\mu\right|^{2}\right] \frac{1}{n_{G_{k}}} \sum_{j=1}^{n_{G_{k}}} \frac{G_{j k}}{\operatorname{mean}(\boldsymbol{G})}
$$


where $n$ is the number of experimental measurements, $\mu$ is the mean of the entire dataset, the index $j$ denotes the available Gini indices in the column $G_{j k}$, and $G$ denotes all of the values in the matrix $G_{i k}[12,14]$.

This method appears to be beneficial for discovering larger-scale geographical correlations, which may then be related to geological features. This is especially intriguing because evaluating and mitigating the risk of radon exposure requires the identification of local geology and its link to radon exhalation.

\section{Results}

Following the measurement study in the Sorrentina peninsula area, 70 values of the average yearly concentrations of Rn in dwellings at 100 measured locations were selected for the analyses. Figure 3 depicts the geographical distribution of the measurement points (circles) and the relative yearly radon concentration value (different colors). The entire investigation was carried out in accordance with an established quality assurance program, and the results acquired by the Lab.RAD laboratory during the comparison met the BfS requirements.

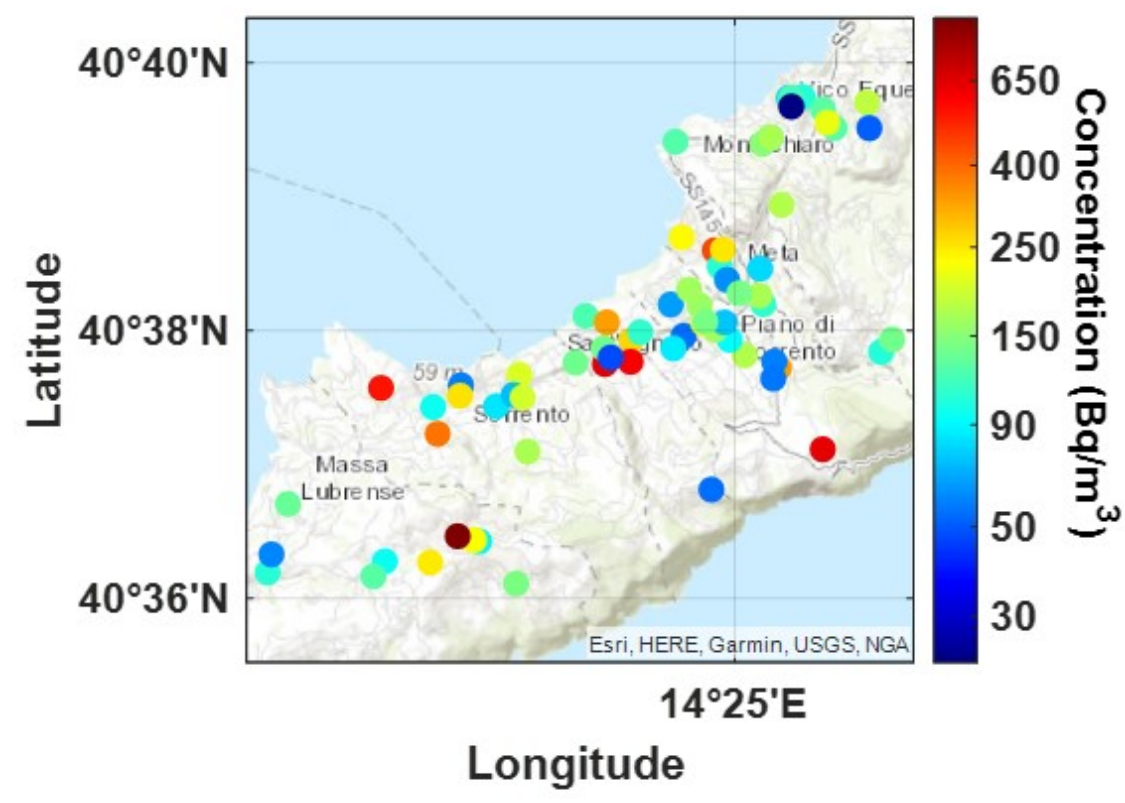

Figure 3. Indoor radon concentrations on the Sorrentina peninsula.

The main findings concern the arithmetic mean (AM), geometric mean (GM), standard deviation (SD), coefficient of variation (CV), geometric standard deviation (GSD), minimum (Min), median (Med), and maximum (Max) for the total measurements on the Sorrentina peninsula, which are reported in Tables 1 and 2, before and after data normalization, respectively. For the monitored dwellings, the conversion factors are $K_{-1 \rightarrow 0}=0.91 ; K_{1 \rightarrow 0}=1.24 ; K_{2 \rightarrow 0}=1.29$.

Tables 1 and 2, and the conversion factor data, allow us to determine how the floor affects the radon concentration values. The AM and GM values following data normalization are greater in relation to the floor than the non-normalized data. 
Table 1. Statistical parameters both for the total measurements on the Sorrentina peninsula and for each municipality before data normalization.

\begin{tabular}{|c|c|c|c|c|c|c|c|}
\hline $\begin{array}{c}\text { Statistical } \\
\text { Parameters }\end{array}$ & $\begin{array}{c}\text { Sorrentina } \\
\text { Peninsula }\end{array}$ & $\begin{array}{c}\text { Massa } \\
\text { Lubrense }\end{array}$ & Meta & $\begin{array}{l}\text { Piano di } \\
\text { Sorrento }\end{array}$ & Sant'Agnello & Sorrento & $\begin{array}{c}\text { Vico } \\
\text { Equense }\end{array}$ \\
\hline $\mathrm{AM}\left(\mathrm{Bq} / \mathrm{m}^{3}\right)$ & 156 & 179 & 152 & 141 & 216 & 178 & 104 \\
\hline $\mathrm{SD}\left(\mathrm{Bq} / \mathrm{m}^{3}\right)$ & 135 & 199 & 97 & 124 & 172 & 152 & 47 \\
\hline $\mathrm{CV}=\mathrm{SD} / \mathrm{AM}$ & 0.87 & 1.11 & 0.64 & 0.88 & 0.80 & 0.85 & 0.45 \\
\hline $\mathrm{GM}\left(\mathrm{Bq} / \mathrm{m}^{3}\right)$ & 120 & 131 & 127 & 109 & 160 & 133 & 92 \\
\hline $\operatorname{GSD}\left(\mathrm{Bq} / \mathrm{m}^{3}\right)$ & 1.35 & 1.38 & 1.31 & 1.36 & 1.44 & 1.41 & 1.26 \\
\hline $\operatorname{Min}\left(\mathrm{Bq} / \mathrm{m}^{3}\right)$ & 25 & 56 & 50 & 42 & 44 & 52 & 25 \\
\hline $\operatorname{Med}\left(\mathrm{Bq} / \mathrm{m}^{3}\right)$ & 108 & 107 & 137 & 120 & 113 & 132 & 100 \\
\hline $\operatorname{Max}\left(\mathrm{Bq} / \mathrm{m}^{3}\right)$ & 722 & 722 & 351 & 513 & 492 & 546 & 204 \\
\hline
\end{tabular}

Table 2. Statistical parameters both for the total measurements on the Sorrentina peninsula and for each municipality after data normalization.

\begin{tabular}{|c|c|c|c|c|c|c|c|}
\hline $\begin{array}{l}\text { Statistical } \\
\text { Parameters }\end{array}$ & $\begin{array}{l}\text { Sorrentina } \\
\text { Peninsula }\end{array}$ & $\begin{array}{c}\text { Massa } \\
\text { Lubrense }\end{array}$ & Meta & $\begin{array}{l}\text { Piano di } \\
\text { Sorrento }\end{array}$ & Sant'Agnello & Sorrento & $\begin{array}{c}\text { Vico } \\
\text { Equense }\end{array}$ \\
\hline $\mathrm{AM}\left(\mathrm{Bq} / \mathrm{m}^{3}\right)$ & 182 & 216 & 178 & 171 & 259 & 188 & 121 \\
\hline $\mathrm{SD}\left(\mathrm{Bq} / \mathrm{m}^{3}\right)$ & 162 & 259 & 115 & 154 & 219 & 149 & 49 \\
\hline $\mathrm{CV}=\mathrm{SD} / \mathrm{AM}$ & 0.89 & 1.20 & 0.65 & 0.90 & 0.85 & 0.79 & 0.40 \\
\hline $\mathrm{GM}\left(\mathrm{Bq} / \mathrm{m}^{3}\right)$ & 139 & 152 & 152 & 130 & 187 & 144 & 108 \\
\hline $\operatorname{GSD}\left(\mathrm{Bq} / \mathrm{m}^{3}\right)$ & 1.36 & 1.40 & 1.29 & 1.37 & 1.45 & 1.39 & 1.27 \\
\hline $\operatorname{Min}\left(B q / m^{3}\right)$ & 23 & 59 & 61 & 55 & 54 & 48 & 23 \\
\hline $\operatorname{Med}\left(\mathrm{Bq} / \mathrm{m}^{3}\right)$ & 135 & 129 & 156 & 151 & 139 & 154 & 123 \\
\hline $\operatorname{Max}\left(\mathrm{Bq} / \mathrm{m}^{3}\right)$ & 933 & 933 & 454 & 632 & 636 & 546 & 216 \\
\hline
\end{tabular}

The trend of the distribution of indoor radon concentration values is commonly recognized in the literature to be of the log-normal type. Figure 4a indicates the frequency distribution of the annual indoor radon concentration for the 70 dwellings, and Figure $4 \mathrm{~b}$ indicates the distribution trend assessed for this study, which matches the expected trend according to the Kolmogorov-Smirnov test ( $p>0.05,95 \%$ confidence level) and the ShapiroWilk test $(p$-value $=0.2)$.
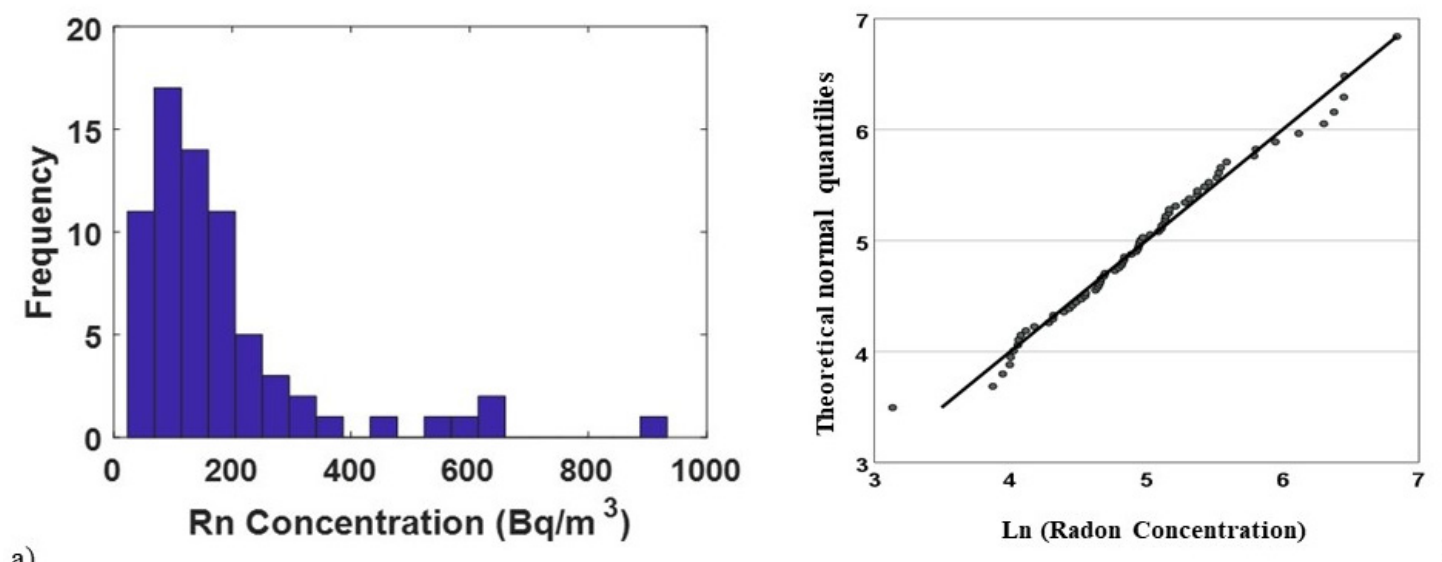

a)

Figure 4. (a) Log-normal distribution of the indoor radon concentration for each dwelling; (b) Q-norm plot of natural log-transformed radon concentration for each dwelling. 
Approximately $13 \%$ of the measurements made exceed the reference level of $300 \mathrm{~Bq} / \mathrm{m}^{3}$ established by the Italian Legislative Decree 101/2020, which transposes the European Directive on Fundamental Safety Standards (BSS)-2013/59 [9].

Soil is thought to be the primary source of indoor radon. Unfortunately, the study was unable to evaluate the relationship between radon concentrations and the geological features of the soil on which the structures were erected. A correlation study, however, was performed using the municipality as the soil's proxy variable.

Figure 5 depicts a box plot of $\mathrm{Rn}$ concentration in $\mathrm{Bq} / \mathrm{m}^{3}$ by municipality. The analysis of variance (ANOVA) method was used to compare different groups (municipality). According to the findings, the municipality has no statistically significant effect on indoor radon levels.

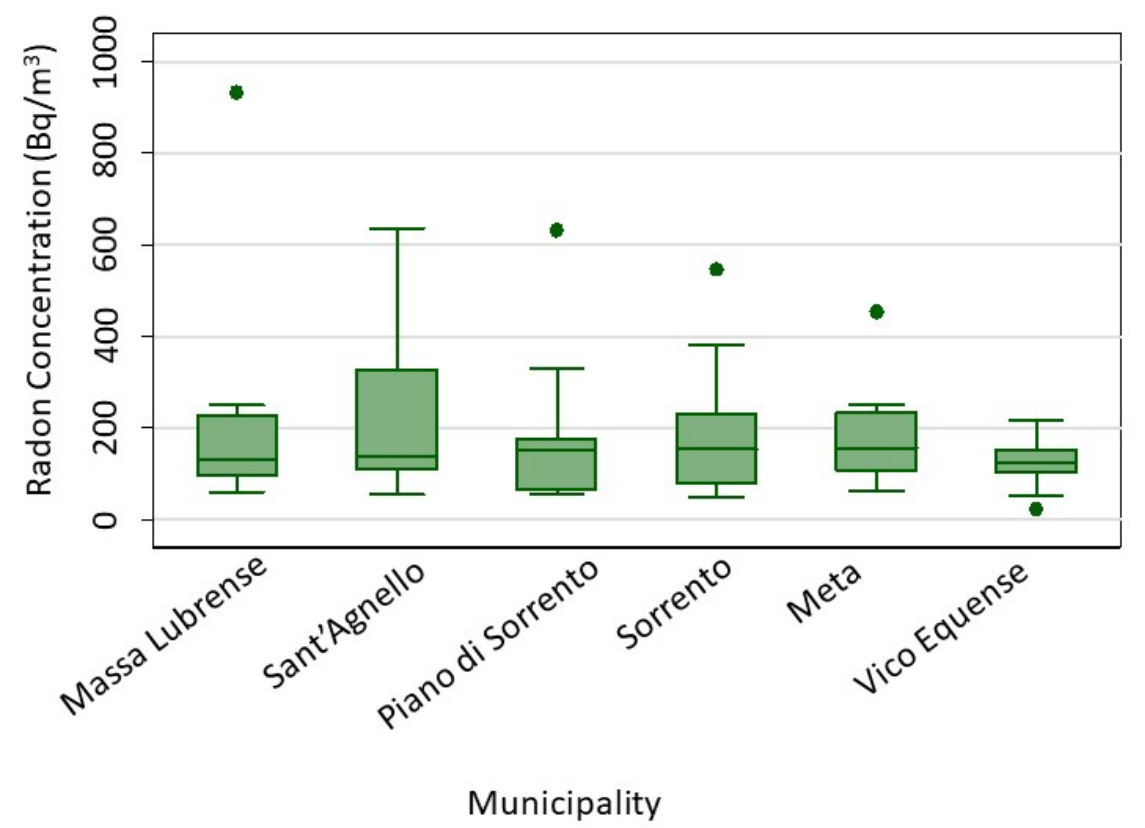

Figure 5. Box plot of Rn concentration in $\mathrm{Bq} / \mathrm{m}^{3}$ by municipality. The continuous line denotes the median, the boxes enclose the quartiles, the dots represent the outliers.

Regarding the study of the spatial autocorrelation of the measures, Figure 6 shows the Gini-based variogram that was obtained after the verification of the behavior of the classical variogram, which describes, in this specific case, a quasi-stationary model.

The variogram has a discontinuity at the origin: $\gamma(h)$ does not tend to zero when $h$ tends to zero, but $\gamma(0)>0$ is observed. A relevant nugget effect can be identified. The presence of the nugget effect is expected in cases of quantities relating to $\mathrm{Rn}[26,27,37]$. In this example, the presence is due to measurements with a high level of error at short distances. Given the size of the investigated area, the amount of data supplied can be regarded to be sufficient for the study.

The geostatistical analysis of the data shows that there is a geographical correlation; the variogram was represented by the following function:

$$
\gamma(h)=S \cdot\left[1-\exp \left(-\frac{h}{R}\right)^{\alpha}\right]+N
$$

where $\alpha=1.5$ [14], the sill was 0.18 , the range was $0.87 \mathrm{~km}$, and the nugget was 0.33 .

The high value of the nugget effect confirms that the indoor radon concentration has a high variability at small spatial scales, as also shown by the measurements. 


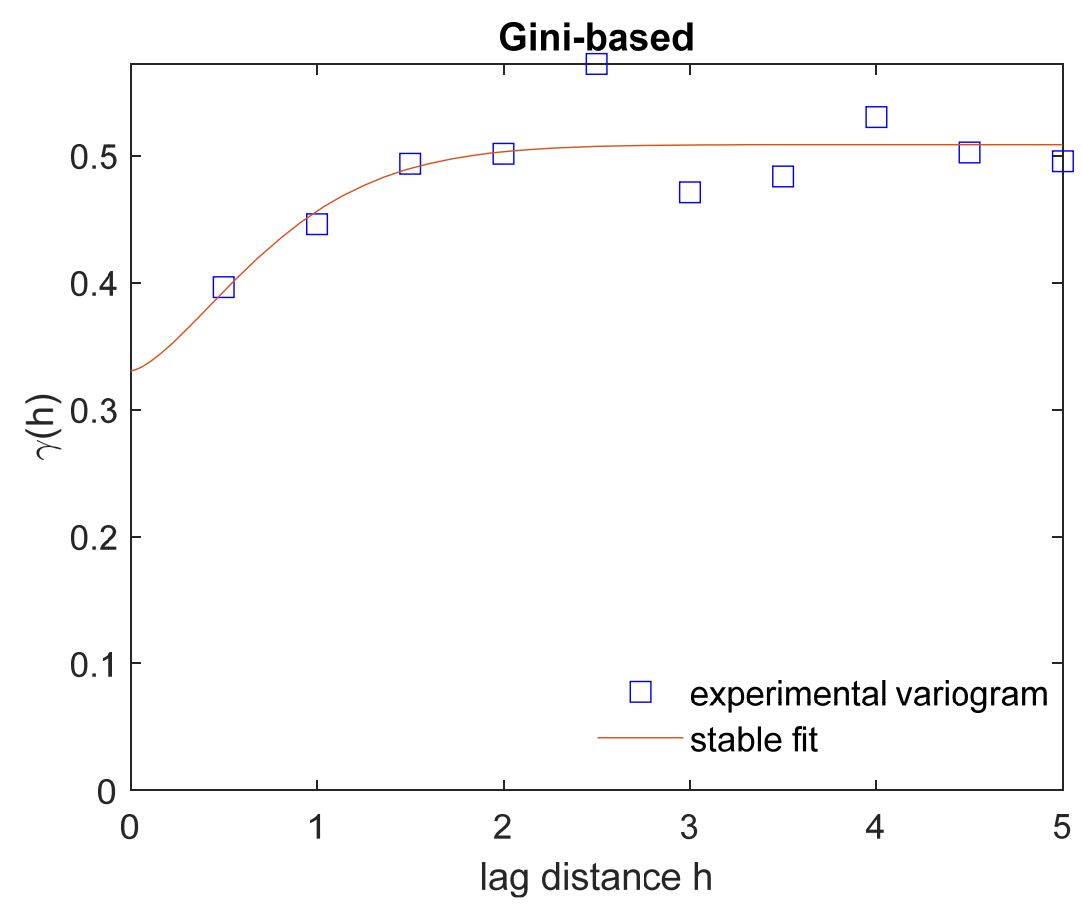

Figure 6. Experimental variogram (blue squares) based on the Gini index for 70 measurement points that were modelled by a stable function (red line).

The variogram's trend was demonstrated at a distance of up to $5 \mathrm{~km}$, for which spatial correlation was ensured. Beyond this distance, the variogram's behavior is indicative of a non-stationarity situation. In this framework, in the Gini-based approach the variogram was computed by clustering a larger number of experimental data. Therefore, the single measurements, possibly affected by a large random uncertainty, were given smaller weights. For this reason, the proposed method appears to be particularly efficient and innovative for the deduction of common source features from indoor radon surveys, where larger uncertainties can be expected [38]. Hence, this approach is potentially advantageous for constraining the different geogenic potential soils at different spatial scales [27,39].

Figure 7 depicts the geographical distribution of radon concentrations in houses. The Gini-method kriging map enabled the identification of locations that operate as homogeneous sources of radon by observing the forecast of radon emission beginning from a real dataset of scattered datapoints in that area. Because a correlation study based on geology has not been undertaken in this context, we can only hypothesize that locations with the highest concentrations of radon can be observed in close proximity to those in which they are present as pyroclastic rocks. Because the long-term goal of this research is to establish an environmental geochemistry map that best portrays reality, this map will progress from point maps to interpolated and exceedance maps, utilizing the current legislation's limit values as a reference. The interpolated maps will be overlaid on geolithological maps of the region to determine the substrate's contribution to the recommended indoor radon values.

Radon potential in a given location is determined by a combination of rock and soil factors, such as uranium and radium levels, porosity, and meteorological conditions [40]. 


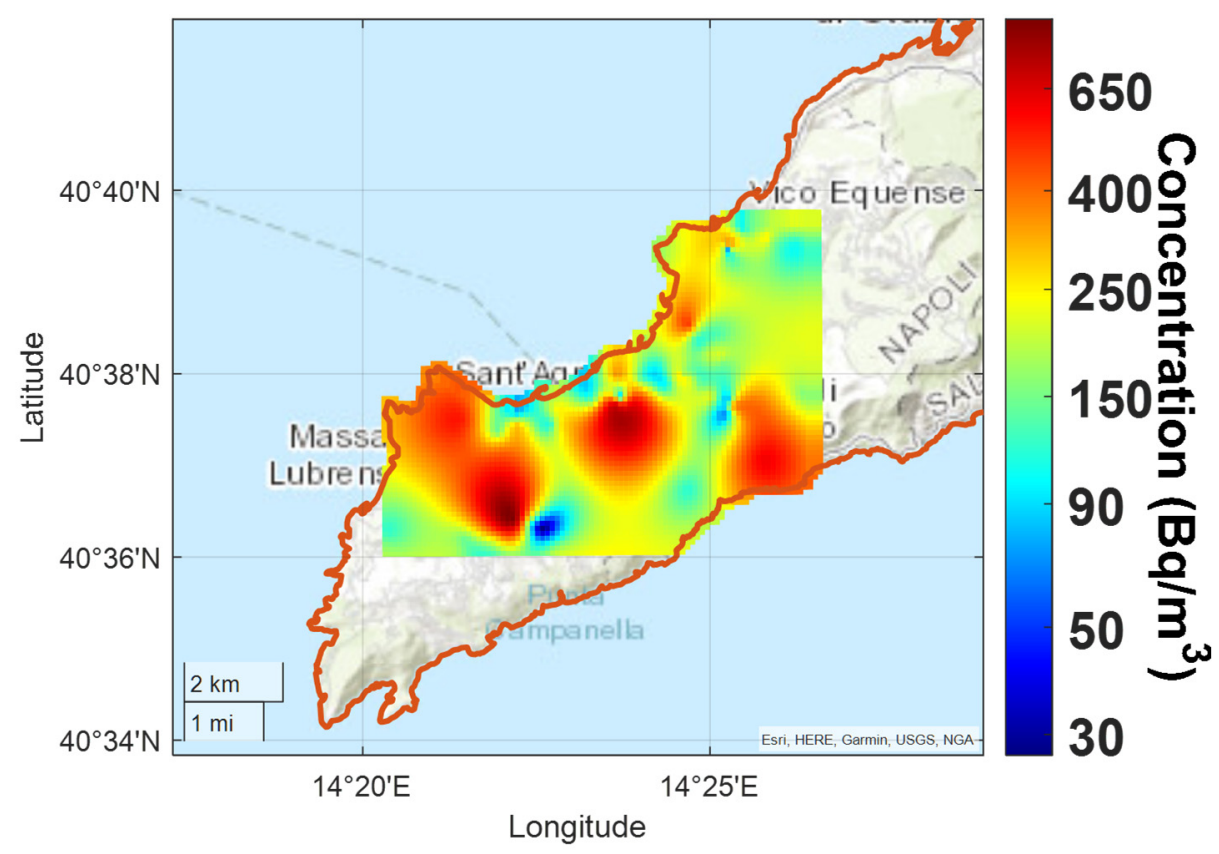

Figure 7. Kriging map obtained with the Gini method for 70 measurement points on the Sorrentina peninsula.

\section{Discussion}

This work shows the results obtained after a measurement survey was carried out in private homes located in some municipalities of the Sorrentina peninsula. The results presented in this work demonstrate the importance of dissemination as a useful process to increase people's awareness of the risks of radon exposure. The monitoring in residences occurred in this study after people were informed of the health dangers associated with exposure to high concentrations of radon, and urged to carry out the measures even if there was no requirement for monitoring in the home. According to the poll, many of those who requested radon testing at their houses were unaware of the dangers of radon.

This study was conducted in a region in which an active volcano is located. Thus, the geology comprises extensive sections of pyroclastic rocks with a high radon concentration. The latter are frequently utilized as building materials, increasing the population's exposure to natural radiation. An example is tuff, which was frequently used in the construction of historic buildings in Campania [41]. In this regard, data preprocessing was performed by selecting, from the 100 monitored structures, only those built in concrete (70 dwellings), and taking advantage of the fact that these structures were numerically prevalent. As a result, the data were independent from the building material and a lower radon emission from the walls of buildings was ensured.

Furthermore, the findings confirm the results of previous research, namely, that radon concentrations have a high dependence on the floor. This assertion can be determined from the value of the conversion factors and, as a result, from AM and GM, which were greater, in terms of the floor, after data normalization compared to non-normalized data (see Tables 1 and 2).

The Legislative Decree 101 [9] establishes the value of $300 \mathrm{~Bq} / \mathrm{m}^{3}$ as the annual average radon concentration that should not be exceeded in all currently existing closed environments; this includes both workplaces and homes. For future buildings (built prior to 2024), the limit will be $200 \mathrm{~Bq} / \mathrm{m}^{3}$. In this study, only a small percentage (approximately $13 \%$ ) of the data exceeded the limit of $300 \mathrm{~Bq} / \mathrm{m}^{3}$.

Because the experimental data were normalized with respect to the building materials and the floor on which the measurement was performed, the dataset was independent of these building characteristics, and it is possible to hypothesize that radon concentrations are due to the geogenic potential of Rn in the observed area. 
Although the map shows a cluster in the vicinity of the area between Sorrento and Massa Lubrense, a geological refinement and integration in the analysis of the geology of the area under study would allow any radon sources to be to classified.

The map represents an estimate of the global distribution of Rn indoor concentrations. As a result of the lack of a comprehensive examination of the geological composition of the monitored region in this study, the area is likely to be classified incorrectly.

Currently, our laboratory is conducting several measurement studies throughout the Campania region [42] that will add to the data presented in this study. This will allow the authors to perform a wider study that may encompass the entire Campania region. Indoor radon measurements and, hence, the development of interpolated maps using the Gini technique, will be accompanied by laboratory and/or in situ measurements of soil samples and/or substrate lithotypes to create geolithological maps. The creation of these maps will enable a study of the relationship between radon concentrations and the geology of the investigated area.

\section{Conclusions}

The "training and information" surveys are currently assisting in raising the knowledge of the dangers of radon gas exposure in dwelling situations. Indoor radon levels were tested in 100 homes on the Sorrentine peninsula in southern Italy. After data preprocessing, the radon concentrations ranged from 23 to $933 \mathrm{~Bq} / \mathrm{m}^{3}$ (70 measurement points). Indoor radon concentrations are primarily impacted by two factors: the region's potential radon and the type of building, both of which were confirmed in this study. Approximately 13\% of the dwellings had radon quantities over the action threshold set by Italian legislation. The kriging map (Gini-based approach) was estimated using the combination of the geographical distribution of measurement points in the territory and radon survey data, thus enabling the estimation of predicted radon levels in the chosen location.

Knowledge of radon dispersion in the environment can contribute significantly to individual radiation safety and prevention, and provide a solution to economic and/or environmental issues related to land use.

In this framework, the proposed approach appears to be particularly efficient for the inference of common source features from indoor investigation surveys, where we can expect larger uncertainties. In this case, the single measurements, which may be affected by a large random uncertainty, are assigned lower weights.

This may be a valuable tool in the planning of new buildings as dwellings and major infrastructure projects, depending on the usage of various building materials and the selection of low-radon-risk regions. In this case, preventive actions can be applied.

In the case of existing facilities, there are a number of mitigation techniques that can be implemented to limit radon exposure indoors. These interventions can be used separately or in combination to limit the primary contribution, which is generally the soil, and exposure from other radon sources (such as building materials). These interventions include substantial natural and forced ventilation, the sealing of the main access ways to radon, the depressurization of the subsoil, and the use of inexpensive sumps [43-45]. These modifications must be tailored to each building, taking into account its architecture, the nature of the subsoil on which it is constructed, and its construction characteristics.

Author Contributions: Conceptualization, F.L.; methodology, F.L. and M.Q.; software, F.L.; validation, F.L.; formal analysis, F.L., I.O.-N. and M.Q.; investigation, F.L.; resources, F.L. and M.Q.; data curation, F.L. and I.O-N.; writing-original draft preparation, F.L., I.O.-N. and M.Q.; writing-review and editing, F.L., I.O.-N. and M.Q.; visualization, F.L., I.O.-N. and M.Q.; supervision, M.Q.; project administration, M.Q.; funding acquisition, F.L. and M.Q. All authors have read and agreed to the published version of the manuscript.

Funding: This research has been supported by the University of Naples Federico II, the Italian Ministry of University and Research (MIUR), within the program PON R\&I 2014-2020-Attraction and International Mobility (AIM)-CUP E61G19000020001. 
Institutional Review Board Statement: Not applicable.

Informed Consent Statement: Not applicable.

Data Availability Statement: The data presented in this study are available on request from the corresponding author. The data are not publicly available due to the non-exclusive ownership by the authors. The data is shared with a third party, "the residents of the study area".

Acknowledgments: The authors are thankful to the residents of the study area for their collaboration to the project.

Conflicts of Interest: The authors declare no conflict of interest.

\section{References}

1. Borkowska, E.; Brudecki, K.; Kostkiewicz, M.; Gorzkiewicz, K.; Misiak, R.; Nalichowska, E.; Miszczyk, J.; Mróz, T. 99mTc internal contaminations measurements among nuclear medicine medical personnel during ventilation-perfusion SPECT lung scans. Radiat. Environ. Biophys. 2021, 60, 389-394. [CrossRef] [PubMed]

2. Savino, F.; Pugliese, M.; Quarto, M.; Adamo, P.; Loffredo, F.; De Cicco, F.; Roca, V. Thirty years after Chernobyl: Long-term determination of 137 Cs effective half-life in the lichen Stereocaulon vesuvianum. J. Environ. Radioact. 2017, 172, 201-206. [CrossRef] [PubMed]

3. Loffredo, F.; Vardaci, E.; Roca, V.; Pugliese, M. Space missions: Comparison of shielding effectiveness among different materials using $1 \mathrm{GeV}$ protons. Mater. Res. Express 2018, 6, 016544. [CrossRef]

4. Caridi, F.; Marguccio, S.; Belvedere, A.; D'Agostino, M. Validation of gamma-ray spectrometry (GRS) for radionuclides analysis of environmental and food samples. SN Appl. Sci. 2019, 1, 256. [CrossRef]

5. Environmental Protection Agency (EPA). EPA Assessment of Risks from Radon in Homes; EPA: Washington, DC, USA, 2003.

6. Garzillo, C.; Pugliese, M.; Loffredo, F.; Quarto, M. Indoor radon exposure and lung cancer risk: A meta-analysis of case-control studies. Transl. Cancer Res. 2017, 6, S934-S943. [CrossRef]

7. Li, C.; Wang, C.; Yu, J.; Fan, Y.; Liu, D.; Zhou, W.; Shi, T. Residential Radon and Histological Types of Lung Cancer: A Meta-Analysis of Case-Control Studies. Int. J. Environ. Res. Public Health 2020, 17, 1457. [CrossRef]

8. Zhang, Z.-L.; Sun, J.; Dong, J.; Tian, H.-L.; Xue, L.; Qin, L.-Q.; Tong, J. Residential Radon and Lung Cancer Risk: An Updated Meta-analysis of Case-control Studies. Asian Pac. J. Cancer Prev. 2012, 13, 2459-2465. [CrossRef]

9. Decreto Legislativo 31 Luglio 2020, n. 101. In Italian. Available online: https://www.gazzettaufficiale.it/eli/id/2020/08/12/20G0 0121 /sg (accessed on 21 June 2021).

10. Ciotoli, G.; Voltaggio, M.; Tuccimei, P.; Soligo, M.; Pasculli, A.; Beaubien, S.; Bigi, S. Geographically weighted regression and geostatistical techniques to construct the geogenic radon potential map of the Lazio region: A methodological proposal for the European Atlas of Natural Radiation. J. Environ. Radioact. 2017, 166, 355-375. [CrossRef]

11. Groves-Kirkby, C.; Denman, A.; Phillips, P. Lorenz Curve and Gini Coefficient: Novel tools for analysing seasonal variation of environmental radon gas. J. Environ. Manag. 2009, 90, 2480-2487. [CrossRef]

12. Loffredo, F.; Scala, A.; Adinolfi, G.M.; Savino, F.; Quarto, M. A new geostatistical tool for the analysis of the geographical variability of the indoor radon activity. Nukleonika 2020, 65, 99-104. [CrossRef]

13. Loffredo, F.; Savino, F.; Serra, M.; Tafuri, D.; Quarto, M. Cognitive investigation on the knowledge of the risk deriving from radon exposure: Preliminary results. Acta Med Mediterr. 2020, 36, 1265-1267.

14. Loffredo, F.; Scala, A.; Serra, M.; Quarto, M. Radon risk mapping: A new geostatistical method based on Lorenz Curve and Gini index. J. Environ. Radioact. 2021, 233, 106612. [CrossRef] [PubMed]

15. Bochicchio, F.; Venuti, G.C.; Nuccetelli, C.; Piermattei, S.; Risica, S.; Tommasino, L.; Torri, G. Results of the Representative Italian National Survey on Radon Indoors. Health Phys. 1996, 71, 741-748. [CrossRef] [PubMed]

16. Bochicchio, F.; Hulka, J.; Ringer, W.; Rovenska, K.; Fojtíková, I.; Venoso, G.; Bradley, E.J.; Fenton, D.; Gruson, M.; Arvela, H.; et al. National radon programmes and policies: The RADPAR recommendations. Radiat. Prot. Dosim. 2014, 160, 14-17. [CrossRef]

17. Bartzis, J.; Zeeb, H.; Bochicchio, F.; Mc Laughlin, J.; Collignan, B.; Gray, A.; Kalimeri, K. An Overview of the Activities of the RADPAR (Radon Prevention and Remediation) Project. In Proceedings of the 11th International Workshop on the Geological Aspects of Radon Risk Mapping, Prague, Czech Republic, 18-22 September 2012. Available online: http://www.radon.eu/ workshop2012/pres/09bartzis_ppt_prague_2012.pdf (accessed on 27 July 2021).

18. Radon Real Time Monitoring System and Proactive Indoor Remediation. Available online: http://www.liferespire.it/ (accessed on 30 July 2021).

19. Bossew, P.; Cinelli, G.; Ciotoli, G.; Crowley, Q.G.; De Cort, M.; Elío Medina, J.; Gruber, V.; Petermann, E.; Tollefsen, T. Development of a Geogenic Radon Hazard Index-Concept, History, Experiences. Int. J. Environ. Res. Public Health 2020, 17, 4134. [CrossRef]

20. Ruano-Ravina, A.; Narocki, C.; Lopez-Jacob, M.J.; Garcia Oliver, A.; de la Cruz Calle Tierno, M.; Peon-Gonzalez, J.; Barros-Dios, J.M. Indoor radon in Spanish workplaces. A pilot study before the introduction of the European Directive 2013/59/Euratom. Gac. Sanit. 2019, 33, 563-567. [CrossRef] [PubMed]

21. Webster, R.; Oliver, M.A. Geostatistics for Environmental Scientists, 2nd ed.; John Wiley \& Sons: Chichester, UK, 2007. [CrossRef] 
22. Adelikhah, M.; Shahrokhi, A.; Imani, M.; Chalupnik, S.; Kovács, T. Radiological Assessment of Indoor Radon and Thoron Concentrations and Indoor Radon Map of Dwellings in Mashhad, Iran. Int. J. Environ. Res. Public Health 2020, 18, 141. [CrossRef] [PubMed]

23. Sabbarese, C.; Ambrosino, F.; D'Onofrio, A.; Pugliese, M.; La Verde, G.; D'Avino, V.; Roca, V. The first radon potential map of the Campania region (southern Italy). J. Appl. Geochem. 2021, 126, 104890. [CrossRef]

24. Giustini, F.; Ciotoli, G.; Rinaldini, A.; Ruggiero, L.; Voltaggio, M. Mapping the geogenic radon potential and radon risk by using Empirical Bayesian Kriging regression: A case study from a volcanic area of central Italy. Sci. Total Environ. 2019, 661, 449-464. [CrossRef]

25. Lima, A.; De Vivo, B.; Cicchella, D.; Cortini, M.; Albanese, S. Multifractal IDW interpolation and fractal filtering method in environmental studies: An application on regional stream sediments of (Italy), Campania region. Appl. Geochem. 2003, 18, 1853-1865. [CrossRef]

26. Borgoni, R.; Quatto, P.; Somà, G.; De Bartolo, D. A geostatistical approach to define guidelines for radon prone area identification. J. Ital. Stat. Soc. 2009, 19, 255-276. [CrossRef]

27. Bossew, P.; Žunić, Z.; Stojanovska, Z.; Tollefsen, T.; Carpentieri, C.; Veselinović, N.; Komatina, S.; Vaupotič, J.; Simović, R.; Antignani, S.; et al. Geographical distribution of the annual mean radon concentrations in primary schools of Southern SerbiaApplication of geostatistical methods. J. Environ. Radioact. 2014, 127, 141-148. [CrossRef]

28. Cafaro, C.; Bossew, P.; Giovani, C.; Garavaglia, M. Definition of radon prone areas in Friuli Venezia Giulia region, Italy, using geostatistical tools. J. Environ. Radioact. 2014, 138, 208-219. [CrossRef]

29. Park, N.-W.; Kim, Y.; Chang, B.-U.; Kwak, G.-H. County-level indoor radon concentration mapping and uncertainty assessment in South Korea using geostatistical simulation and environmental factors. J. Environ. Radioact. 2019, 208-209, 106044. [CrossRef]

30. Petermann, E.; Bossew, P. Mapping indoor radon hazard in Germany: The geogenic component. Sci. Total Environ. 2021, 780, 146601. [CrossRef] [PubMed]

31. Sarra, A.; Fontanella, L.; Valentini, P.; Palermi, S. Quantile regression and Bayesian cluster detection to identify radon prone areas. J. Environ. Radioact. 2016, 164, 354-364. [CrossRef]

32. Aucelli, P.; Cinque, A.; Mattei, G.; Pappone, G. Historical sea level changes and effects on the coasts of Sorrento Peninsula (Gulf of Naples): New constrains from recent geoarchaeological investigations. Palaeogeogr. Palaeoclim. Palaeoecol. 2016, 463, 112-125. [CrossRef]

33. Brancaccio, L.; Cinque, A.; Romano, P.; Rosskopf, C.; Russo, F.; Santangelo, N. L'evoluzione delle pianure costiere della Campania: Geomorfologia e neotettonica, Assetto fisico e problemi ambientali delle pianure italiane. Mem. Della Soc. Geogr. Ital. 1995, LIII, 313-336.

34. Ferranti, L.; Antonioli, F.; Anzidei, M.; Monaco, C.; Stocchi, P. The timescale and spatial extent of vertical tectonic motions in Italy: Insights from relative sea-level changes studies. J. Virtual Explor. 2010, 36, 30. [CrossRef]

35. Milia, A.; Torrente, M.M. Tectono-stratigraphic signature of a rapid multistage subsiding rift basin in the Tyrrhenian-Apennine hinge zone (Italy): A possible interaction of upper plate with subducting slab. J. Geodyn. 2015, 86, 42-60. [CrossRef]

36. Sarra, A.; Nissi, E.; Palermi, S. Residential radon concentration in the Abruzzo region (Italy): A different perspective for identifying radon prone areas. Environ. Ecol. Stat. 2011, 19, 219-247. [CrossRef]

37. Raspa, G.; Salvi, F.; Torri, G. Probability mapping of indoor radon-prone areas using disjunctive kriging. Radiat. Prot. Dosim. 2009, 138, 3-19. [CrossRef]

38. Trotti, F.; Biancotti, R.; Lanciai, M.; Mozzo, P.; Predicatori, F.; Tacconi, A. Indoor Exposure to Natural Radioactivity in Veneto. Radiat. Prot. Dosim. 1994, 56, 309-313. [CrossRef]

39. Borgoni, R.; Tritto, V.; Bigliotto, C.; De Bartolo, D. A Geostatistical Approach to Assess the Spatial Association between Indoor Radon Concentration, Geological Features and Building Characteristics: The Case of Lombardy, Northern Italy. Int. J. Environ. Res. Public Health 2011, 8, 1420-1440. [CrossRef] [PubMed]

40. Beaubien, S.E.; Ciotoli GLombardi, S. Carbon dioxide and radon gas hazard in the Alban Hills area (central Italy). J. Volcanol. Geotherm. Res. 2003, 123, 63-80. [CrossRef]

41. Quarto, M.; Pugliese, M.; Loffredo, F.; Roca, V. Indoor radon concentration measurements in some dwellings of the Penisola Sorrentina, South Italy. Radiat. Prot. Dosim. 2013, 156, 207-212. [CrossRef] [PubMed]

42. Loffredo, F.; Savino, F.; Amato, R.; Irollo, A.; Gargiulo, F.; Sabatino, G.; Serra, M.; Quarto, M. Indoor Radon Concentration and Risk Assessment in 27 Districts of a Public Healthcare Company in Naples, South Italy. Life 2021, 11, 178. [CrossRef] [PubMed]

43. Denman, A.; Groves-Kirkby, C.J.; Coskeran, T.; Parkinson, S.; Phillips, P.; Tornberg, R. Evaluating the health benefits and cost-effectiveness of the radon remediation programme in domestic properties in Northamptonshire, UK. Health Policy 2005, 73, 139-150. [CrossRef]

44. Long, S.; Fenton, D.; Cremin, M.; Morgan, A. The effectiveness of radon preventive and remedial measures in Irish homes. J. Radiol. Prot. 2013, 33, 141-149. [CrossRef]

45. Denman, A.; Sinclair, J.; Phillips, P.; Crockett, R.; Groves-Kirkby, C.J. The cost effectiveness of radon reduction programmes in domestic housing in England and Wales: The impact of improved radon mapping and housing trends. Environ. Int. 2013, 59, 73-85. [CrossRef] 